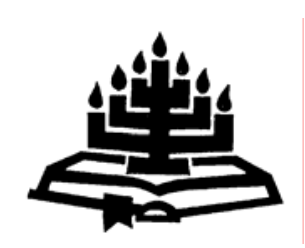

\title{
Attempting a first translation of the Septuagint psalms into Afrikaans: problems and challenges
}

\author{
Gert J. Steyn \\ Department of New Testament Studies \\ University of Pretoria \\ PRETORIA \\ E-mail: gert.steyn@up.ac.za
}

\begin{abstract}
Attempting a first translation of the Septuagint psalms into Afrikaans: problems and challenges

A translation project was started during October 2004 with a small number of senior students in order to translate the Septuagint ( $L X X)$ psalms into Afrikaans for the first time. The importance of the LXX for Christianity cannot be overestimated and this is an attempt to make people aware of this important first translation of the Jewish Scriptures on the African continent, to give people access to it in a translation in their mother tongue, and to contribute to the importance of the psalms as a collection of hymns and prayers that is of value for the liturgy and the ministry of the church. However, a number of significant problems were encountered, among them the fact that (a) no satisfactory Greek critical text edition of the LXX psalms exists currently; (b) the LXX is already a translation from the Hebrew; (c) words have different connotations and meanings in the receptor language (Afrikaans) for different members in the group; (d) being poetic language, to what extent would a literal or a dynamic translation be more appropriate?; (e) given the pace of translation and the extent of the project, it will take quite a number of years to complete; and (f) existing dictionaries and grammars are mainly focused on the New Testament - not on the LXX. These problems are discussed by means of practical examples encountered in Psalms 1-3.
\end{abstract}




\section{Opsomming}

'n Poging tot 'n eerste vertaling van die Septuaginta psalms in Afrikaans: probleme en uitdagings

Gedurende Oktober 2004 is 'n vertalingsprojek begin met 'n klein groepie senior studente ten einde die Septuaginta (LXX) psalms vir die eerste keer in Afrikaans te vertaal. Die belang van die LXX vir die Christendom kan nie onderskat word nie. Hierdie is 'n poging om mense bewus te maak van dié eerste belangrike vertaling van die Joodse Skrifte op die Afrikakontinent, sodat toegang daartoe in die spreektaal verkry kon word. Voorts is dit ook ' $n$ poging om by te dra tot die belang van die psalms as 'n versameling himnes en gebede wat van waarde is vir die liturgie en die bediening van die kerk. 'n Aantal beduidende probleme het egter tydens die vertalingsproses na vore getree, waaronder die feit dat (a) geen bevredigende krities-eklektiese uitgawe van die LXX psalms tans bestaan nie; (b) die $L X X$ alreeds 'n vertaling van die Hebreeus is; (c) woorde verskillende betekenisse in Afrikaans het vir verskillende lede in die groep; (d) aangesien dit poëtiese taal is, tot watter mate sou 'n letterlike of 'n dinamiese vertaling meer gepas wees?; (e) gegewe die pas van die vertaling en die omvang van die projek, gaan dit 'n klompie jare neem om te voltooi; en (f) bestaande Griekse woordeboeke en grammatikas fokus hoofsaaklik op die Nuwe Testament - nie op die LXX nie. Hierdie probleme word bespreek aan die hand van praktiese voorbeelde wat in Psalms 1-3 raakgeloop is.

\section{Introduction}

An Afrikaans translation of the Septuagint (LXX) psalms and odes does not exist to date according to my knowledge. During October 2004 such a translation project was started with a small number of senior students in order to attempt addressing this issue. What follows here is in one sense a progress report regarding the project (focusing on Psalms 1-3), and in another sense an opportunity to enter into dialogue with other translators and scholars about the merit and viability of such a translation project.

The importance of the LXX for both early Christianity and modern day Christianity cannot be underestimated and need not to be substantiated here. Our humble translation project is an attempt to make Afrikaans speaking people aware of this important first translation of the Scriptures into Greek, and to give them access to it in an Afrikaans translation, and to contribute to the importance of the psalms as a collection of hymns and prayers which continue to be of 
value for the liturgies and the ministries of the church. The Psalter had been a hymn-book and a prayer-book of the Christian church from the earliest times and "was used to set forth their profoundest beliefs concerning the Lord" (New Bible Dictionary, 1962:984).

Several aspects thus triggered the need of the attempted translation of the LXX psalms and odes into Afrikaans:

- The LXX (at least the Pentateuch) was the first known translation of the Scriptures to be undertaken on this scale on the African continent. Afrikaans, on the other hand, is an African language one of the youngest - that had its origins also on this continent.

- Although the LXX had been translated into a number of other languages, it has not yet been translated into Afrikaans.

- Major projects were recently undertaken to translate the LXX into modern day languages, such as the project of the New English Translation of the Septuagint (NETS) and the first German translation. 1 These are not only indications of a renewed and growing interest in the value of the LXX for Jewish and Christian studies, but those translations also have a contagious effect on other languages.

- The psalms and odes as a collection lends itself easier to smaller units that can be translated on its own as time permits within the busy schedules of those involved in the process.

- A translation project of this nature assists in stimulating new research. Students involved soon realised the importance of the LXX as a corpus of literature in its own right. Apart from the contents presented and the theology of the first translator, also aspects regarding textual criticism, language, grammar and translation techniques (ancient and modern), contributed to the discovery of a range of issues that ought to be investigated.

- Being present for a short period during the Josephus translation project of Folker Siegert in Münster, Germany, during the Wintersemester of $2002 / 2003$, lead to a personal desire to establish a similar interest group of translators among local students. Those

1 See Cook (2005:534-536) for a brief overview of the French, English and German translation projects. 
who were involved in advanced research in Ancient Langauges at the University of Pretoria were invited to join this reading group. ${ }^{2}$

A number of clear goals were then set regarding our approach and working methodology within the first few sessions. Firstly, we decided to make a fairly literal translation with footnotes, in order to explain certain important aspects regarding the meaning of a word or phrase. This was preferred with the rationale to provide a working translation that would be of help mainly to students and scholars in theology and one that could assist with an easy comparison of the Greek text, rather than a paraphrase or even dynamic translation equivalent version. Secondly, we would nonetheless strife to translate into an Afrikaans idiom that is well understood by the current young generation. If the project would only be completed within the next ten to twenty years, the users would mainly be the current teenage generation. The proposed age range of 25-35 by Nida and Taber (1974:182) was thus reduced with another decade with today's late teens in mind. Thirdly, we would avoid both the Hebrew text as well as current (particularly Afrikaans) translations. Only the Greek text would be used as the sole source text for the translation. This approach is thus similar to that of the French project which takes the LXX as a "free-standing, replacement translation" (Pieters$\mathrm{ma}, 2002: 340$ ) and as a project that "places the focus on the Greek text", studying "the Septuagint for its own sake, 'pour elle-même', 'an sich"' (Cook, 2005:535). Fourthly, we decided to remind ourselves constantly that we are not busy with the writing of either a grammatical or a theological commentary, but that our task is merely that of translating the text. This became the most difficult criterion to adhere to as we learnt that it was almost impossible to translate unless one first understand what the author actually meant with his text. The result was that we actually analysed the text in a commentary manner in order to grasp something of its meaning before we could attempt translating it.

\section{Problems and challenges}

As from the very first session, the group members encountered a number of significant problems. The most striking were the fact that no satisfactory Greek critical text edition of the psalms exists; that the LXX is already a translation from the Hebrew; that words have

2 With gratitude to the commitment of Peter Nagel, Larry van der Walt, Ronald van den Berg, Johannes Mahne, Louis Mynhardt and others who commitedly assisted on a continuing basis in the translation process. 
different connotations and meanings in the receptor language (Afrikaans) for different members in the group; that being written in poetical language, it became difficult to determine to what extend a literal or a dynamic translation would be more appropriate; that given the pace of translation and the extend of the project, it will take quite a number of years to complete; and that existing dictionaries and grammars are mainly focused on the New Testament - not on the LXX.

\subsection{No satisfactory critical text edition of the Greek psalms exists}

Alfred Rahlfs' first general edition of "the" LXX, his Psalmi cum Odis, was published in 1931 as part of the critical text series compiled at Göttingen. Rahlfs identified six families of textual witnesses. Jellicoe (1989:297) wrote of this edition:

As a critical edition of the Psalter this volume, despite its 365 pages which include 71 of useful prolegomena, falls far short of the desiderata. The apparatus criticus is little more than that of an editio minor ... Of the Psalter more manuscripts are available than any other part of the Greek Bible, yet of these direct use is made of comparatively few.

A new edition was published in 1967, but was basically an orthographical improvement and did not include many more manuscripts than those of the 1931 edition. This edition was reprinted without any changes in 1979.

Since the discoveries at Qumran and in the vicinity of the Dead Sea, a number of manuscripts - including the psalms - became part of the pool of textual witnesses that are available in the reconstruction of the text of the psalms. Fernández Marcos (2000:70) is actually of the opinion that "[I]t is difficult to overestimate the impact made by the finds from the Desert of Judah on the understanding of the history of the Biblical text and more particularly on the early history of the LXX and its relationship to the Hebrew text".

The tradition and redaction history of the Psalter collections is a complex terrain. Flint (1997:170-171) reconstructs a situation of multiple collections of the Psalter in the late Second Temple period based on the Dead Sea Psalm Scrolls and distinguises five possible collections:

- An early collection of Psalms which ended with Psalm 89 ("Edition I") 
- A two-part Psalter, attested by $11 \mathrm{QPs}^{\mathrm{a}}$ Psalter

- The proto-Masoretic Psalter with the 150 Psalms

- A Psalter with an arrangement as represented in $4 Q P s^{f}$

- A small collection as contained in 11QPsAp ${ }^{a}$

He identifies then at least three literary editions:

- Psalm 1/2 to 89 [Possible traces in $4 \mathrm{QPs}^{\mathrm{a}}+4 \mathrm{QPs}^{\mathrm{c}}+11 \mathrm{QPs}^{\mathrm{c}}$ ?]

- Edition Ila: $11 \mathrm{QPs}^{\mathrm{a}}\left[\mathrm{Ed} \mathrm{I}+11 \mathrm{QPs}^{\mathrm{a}}\right]$. Traces in 4QPs ${ }^{\mathrm{e}}, 11 \mathrm{QPs}^{\mathrm{b}}$

- Edition Ilb: MT=150 Pss [Ed I + Pss 90-150]. Traces in MasPs ${ }^{b}$

Thus, a good critical text that incorporated the most important manuscript witnesses of the psalms does not exist and will probably only be available in 2015 according to a personal discussion with the now deceased Dr. Quast of the Septuaginta Unternehmens in Göttingen. We decided therefore to follow the 1979, 3rd unchanged edition of Alfred Rahlfs. We chose not to spend time in reconstructing the text from all the available witnesses ourselves and saw our task merely as that of translators of the only existing reconstructed text available to date.

\subsection{The LXX is already a translation from the Hebrew}

We have deliberately chosen not to consult the Hebrew text for two main reasons. Firstly, because this would lead in itself to a comparison of the Hebrew and Greek texts, which is an interesting venture but which would considerably delay our translation process. Secondly, because this would lead to a myriad of detours regarding the possible Vorlage and different text versions that might underlie each of the LXX psalms.

Having made these choices, we realised though, that we were translating an existing translation. This became evident when we were confronted with the Greek translation equivalents such as nomo , dia y a ma, crist ob, tw/Dauid, et cetera. The following comments by scholars on specific terminology used in the LXX, will illustrate this point of the transition from the Hebrew to the Greek text.

- Psalm 1:1: According to Siegert, "Der Hebraismus derek 'Weg' für etwas durchaus Abstrakteres, nämlich den 'Lebenswandel', das 'Verhalten', wird Gewohnheit seit Gen 6,12: 'es verdarb jedes Fleisch seinen Weg'. Ps. 1,1 und über 600 weitere Stellen fixieren die Vokabelgleichung derek $=0$ llot, die in der Kirchen- 
sprache erst in unseren Tagen sich in Synonyme aufgelösen beginnt." (Siegert, 2001:220.)

- Psalm 1:2: The choice for mel et a ǹ as translation equivalent was probably influenced from the Greek rhetoric and philosophy (Siegert, 2001:246). "Diese תורה aber ist nicht der tötende no mo , sondern die lebenbringende, heilsame Offenbarungsgröße der damals vorliegenden Heiligen Schrift (vgl. Ps. 119)." (Kraus, 1978:141.)

- Psalm 1:4: "G fügt an dieser Stelle in nachdrücklicher Beteuerung ein ouf oußkw ein, das zu der Einsetzung von לא כן in $M$ Anlaß geben kann, zumal erst dieser Zusatz dem spärlicher Versteil seine Gestalt gibt." (Kraus, 1978:132.) The LXX repeated the Hebrew lo'-ken a second time in Psalm 1:4a and inserted a p 0; proswpou th $\sim$ gh $\sim$ in Psalm 1:4b (Prinsloo, 2000:2). This insertion should be understood as "ausmalende Hinzufügung" (Kraus, 1978:132).

- Psalm 1:5: Siegert (2001:298) refers to possible Messianic influence in the psalms, such as in Psalm 1:5 and 2:7. "In Jerusalem regierte kein Gesalbter; man dachte also mehr oder weniger zwangsläufig an einen künftigen Messias." One also finds in Psalm 1:5 and 2:1 examples of how a judgment saying could be strengthened: "'Die Gottlosen werden im Gericht nicht aufstehen (ouk ajasthsontai ej krigei): Das Hebräische jaqumu besagte zunächst, sie 'werden nicht bestehen (können) im (jeweiligen) Gericht'. Dies wird nun interpretatorisch eingeengt auf die Vorstellung einer Auferstehung in einem Gericht im besonderen, singularischen Sinne, nämlich im Weltgericht." (Siegert, 2001:299.) Jobes also refers to "an eschatology that involved personal resurrection at the final judgment ... that apparently developed within Judaism in the Hellenistic period". The Hebrew reads "Therefore the wicked will not stand in the judgment', whereas the Greek has, 'Therefore unbelievers will not arise in the judgment'. The semantic range of the Hebrew word qûm includes both arising and standing. The Greek verb chosen by the translator, anistēmi, means specifically 'to rise up', and the New Testament writers use it with reference to resurrection." (Jobes, 2000:96; cf. also p. 301.) According to Van Uchelen (1979:14), "In de joodse overlevering wordt de stam qūm vertaald met het oog op het goddelijke eindgericht (LXX, Targum, Midrasj; ook Vulgata: resurgent), maar de betekenis 'opstaan' geldt alleen waar sprake is van gestorvenen." Vos (2005:55) though, is here of a different opinion: "Psalm 1:5, due to the parallelism it con- 
tains, does not refer to the final judgment, but to the judicial authority in the judicial assembly (at the gate, or in the courthouse)." "G hat offensichtlich בעצת statt בעדת gelesen und übersetzt ej boul hl doch ist $M$ fraglos vorzuziehen." (Kraus, 1978: 132.)

- Psalm 2:1: It is interesting that the New Testamentic quotations from Psalm 2 in Acts 4:25, Hebrews 4:7 and Hebrews 11:32 ascribe this Psalm to David, although his name does not appear in the heading of the reconstructed LXX edition (Siegert, 2001:320). Psalm 2:1 was quoted in 4QFlor 1 - also known as 4QMidrEschat in combination with 4QTest after the work of Steudel (1994) - in combination with 2 Kings (Sam.) 7:10b-14. This combination between Psalm 2 and 2 Samuel 7 would later be followed by New Testament authors such as Luke and Hebrews who are showing knowledge of these two linked passages (cf. Steyn, 1995:170; 2003:263-264, 271). Psalm 2:1-2 would also later be quoted in Acts 4:25-26 (cf. Steyn, 1995:170).

- Psalm 2:2: 0J cris t of as Messianic title is a clear Hebraism with the presence or inclusion of the article, being used substantively. The inclusion of the article in cases such as these are usually the exception. "Bis hin zum Neuen Testament blieb dieser Ausdruck selten." (Siegert, 2001:271.) Aquila chose here "ēleimmenos rather than christos, both of which mean 'anointed' (Jobes, 2000: 39). The Jewish tradition already interpreted this Psalm in a messianic manner and the New Testament links onto this interpretation (Prinsloo, 1984:24), although there are no direct indications in the contents of the psalm itself of Christological inclinations (Prinsloo, 1984:46).

- Psalm 2:2; 3:3, 5: diay al ma. Based on the lexicon of LustEynikel-Hauspie (1996), the term is a neologism used in the LXX, appearing 73 times in the Writings - without Chronicles, 3 times in the later prophets and 5 times in books which do not occur in the Hebrew Bible (Schröder, 2001:61, 63). It replaces the Hebrew sela - which is not present here at this point in the MT - and is, according to Siegert (2001:319), an "Ersatz eines vergessenen und/oder in der Synagoge gegenstandlosen Opferterminus". Lamparter (1961:36) understood sela as "kein Pausenzeichen, sondern ein musikalisches Zeichen für den Vortrag (bzw. die instrumentale Begleitung) des Psalms. Es verleiht dem Vers jeweils besonderen Nachdruck und gibt vermutlich den Instrumenten das Zeichen zu kräftigem Einfallen oder Aushalten." There are thus two problems facing us here: the occurrence of diay a l ma at this 
particular place in the Psalm, and presenting itself as a translation of the Hebrew sela.

- Psalm 2:3: Van Uchelen (1979:20) pointed out that "Met vijf werkwoordsvormen in de gebiedende wijs worden zij gemaand in het gareel te lopen en het 'juk' (LXX bij vs. 3) te dragen, dat wil zeggen God te dienen." According to Kraus (1978:143), the word yoke used in the LXX and in Codex $x$ is not an accepted alternative for the reconstructed Hebrew text. Whether or not this is acceptable in the reconstruction of the Hebrew text is irrelevant for our purposes here. Fact is, this is the word that is used by the translators of the LXX and this is what ought to be translated into Afrikaans.

- Psalm 2:4: Since the Jewish tradition transferred into the Greek language, laugh as an emotion was underplayed - if not banned at all. "Lachen ist Sache der Feinde Israels und deswegen zu dämpfen ... Gott selbst 'lacht' über seine Feinde (Ps. 2, 4). Das ist ein sarkastisches Lachen, keines aus Freude." (Siegert, 2001: 171.)

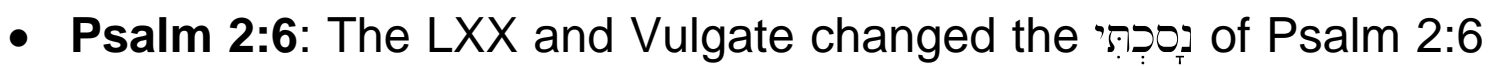
to a passive. According to this change Yahweh is then no longer the speaker here, but the king (Prinsloo, 1984:48). The LXX follows thus a slightly different reading: $F g w ;$ de; kat es $t$ aghn bas il eu; up jaut ou, which is closer to a Hebrew reading such

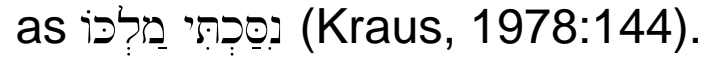

- Psalm 2:8: The LXX uses dws w soi in order to qualify the suffix of the second person (ואיצת: (Kraus, 1978:144).

- Psalm 2:9: The LXX, Vulgate, Hieronymus and the Syriac translation read "you will let them graze" (Jy sal hulle laat wei, or better, jy sal hulle regeer) in stead of "you will smash them" (Jy sal hulle stukkend slaan) (Prinsloo, 1984:49). The LXX reads the

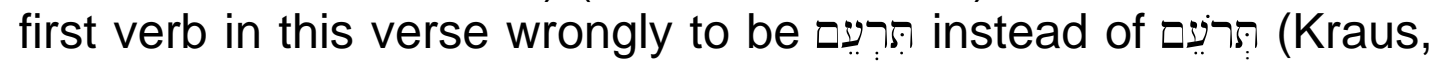
1978:144). The metaphor of "ruling" as expressed by the verb poima inein is a well established one in the Old Testament.

- Psalm 2:9: ej r $\mathrm{abdw/sidhra/according} \mathrm{to} \mathrm{Conybeare} \mathrm{and} \mathrm{Stock}$ (1981:82) refer to the use of en here as one which "includes the instrumental use, but goes far beyond it. Under this aspect en invades the domain of met a vand sum. In most cases it may be rendered by the English 'with'”. 
- Psalm 2:11: Although there are cases where the perceived "terrible" God of the Hebrew text became the God whom one should trust in, most of the time the f obo K uriou (Ps. 2:11 LXX) remained (Siegert, 2001:232). This poses a real difficulty translating die Here vrees. Firstly, the last word itself is not in everyday use except in fixed expressions such as ek is bevrees, or ek vrees dat ... Secondly, in terms of a New Testament understanding of God, a theological concept that expresses fear as a fundamental element in worshiping God, does not make sense to a younger generation.

- Psalm 2:11, 12: The LXX translates here "You should rejoice in him with trembling. Accept (grab) the teaching/education" (Verheug julle in hom met bewing. Aanvaar (gryp) die lering/ onderrig). Aquila, Symmachus and Hieronymus translate "Worship in a pure manner" (Aanbid op suiwere wyse) (Prinsloo, 1984:50, 51).

- Psalm 2:12a: "De LXX en de Targum lezen hier (via Jes. 30:9) een toespeling op de wet of de leer." (Van Uchelen, 1979:22.)

- Psalm 3: "Whatever the precise reason, the Greek text reads more like a description of a past incident than does the MT." (Pietersma, 2003:647.) The same applies to Psalm 1:1.

- Psalm 3:1: Van Uchelen (1979:24) informs about the heading: "Met het opschrift van vs.1 wordt de rij van Davidspsalmen geopend (Psalm 3-41). De typering mizmōr (LXX: psalmos) komt zevenenvijftig maal als technische term boven de psalmen voor en duidt op een gezang." Pietersma makes an important remark about possible Davidic authorship: that $t w / D$ a uid "serves to indicate Davidic authorship, whatever its Hebrew counterpart may be thought to mean, is most unlikely ... Greek exegetical tradition did not uniformly construe it as a nota auctoris, and neither did the translator himself" (Pietersma, 2003:649). "Die in $G$ überlieferte Lesart en tw/gew/a uf ou' = באלהיו würde der spöttischen Rede einen noch kräftigeren Ausdruck verleihen, doch nimmt die Übersetzung in G nur den Dat. iל auf." (Kraus, 1978:157.) Keeping all this in mind, our committee decided to rather translate ' $n$ Dawidspsalm - which indicates the ascribed relation with David, but does not hold him to be necessarily its author.

- Psalm 3:4: Swete (1914:326) already referred to the fact that the translator exchanged the difficult word מָז for the "more intelligible 
word" a jht il hmptwr for its Greek readers. Kraus (1978:157) wonders if the translators probably have read here סִערי 19.

- Psalm 3:7: f obeis̀qai a pov“The great use of prepositions after verbs is one of the main characteristics of Biblical Greek. It is partly a feature of later Greek generally, but to a still greater extent it is due to the influence of the Hebrew." (Conybeare \& Stock, 1981:88.)

- Psalm 3:7: Given a broad range of possibilities in Greek, by choosing the translation equivalent sunepitiqesqai, the LXX translator(s) of Psalm 3:7 displayed "die diskrete Kunst, mit der von den Geschickteren (zu übersetzten) ... Hier entspricht tiqedem Verbum šit, ej i - der Partikel 'al und sun- verstärkt kukl w/ vermeidet übrigens auch den Hiatus" (Siegert, 2001:137).

- Psalm 3:8: "G liest an dieser Stelle mat a iw , was dem hebr. חִִ̣ entspräche." (Kraus, 1978:157.)

\subsection{Words have different connotations and meanings in the receptor language (Afrikaans) for different members in the group}

We are fully aware of the fact that we were choosing translation equivalents in order to express the meaning of the source language into the receptor language. The fact that words do not have meaning but that we rather use words to express meaning became again vividly clear during our venture. The remark by Eugene Nida (1981: $110)$ that "[T]he process of transfer is far more complex than what might appear to be the case, and this is especially true in dealing with the translation of religious texts", was experienced in its fullest sense. We encountered a number of difficulties in this regard. To mention just two:

\section{- Working on a third-level translation:}

By consulting dictionaries in our quest for the best translation equivalent, we realised that we had to translate the English or German translation equivalents of the Greek words in the dictionaries into Afrikaans. This meant that the Greek words of the LXX as translations of the Hebrew, were translated in the dictionaries by means of a number of translation equivalents into English or German, which, in turn, now had to be translated into Afrikaans! Due to the lack of Greek-Afrikaans lexicons, we had to struggle word-byword in order to establish what the best Afrikaans word would be to assist in conveying the meaning of the Greek in its context. 


\section{- Semantic differences between Afrikaans words:}

Older generations who grew up with an Afrikaans Biblical language as determined by the Ou Afrikaanse Vertaling of 1933 (revised in 1953), are still familiar with the meaning of many of those words. The current generation of high school children ( $X$ and Millennium generations), might still use the very same words, but these have been adapted to new contexts. New words, or phrases, had to be looked for in order to convey the meaning of the LXX as closely as possible. Existing dictionaries helped in determining the semantic domains to which the Greek words belong to, but many hours were spent to decide which Afrikaans word(s) - used by the younger generation today - captures that meaning the best.

A few representative examples from Psalm 1 will prove the point (refer to the Annexure):

- a ś ebwǹ (Ps. 1:1, 4, 5): The group had difficulties translating an ordinary word such as this. Goddeloses is understood to be merely "naughty" by the younger generation, or, to a much lesser extend, to be agnostics who do not believe in any god at all. We had to explain the meaning by means of a footnote and decided to continue using the word goddeloses with this qualification.

- oflow (Ps. 1:1, 6): The phrase combining oflow with a mart wl wǹ, dikaiwn and a sं ebwǹ cannot simply be translated with pad/weg van oortreders, pad van regverdiges and pad van goddeloses. The imagery used here refers not in the first instance to a physical road, but rather to a lifestyle, attitude or behaviour. Our group decided to rather use koers in Psalm 1:6 to link with the verbs ginwskei and apol eitai. However, rigting was chosen to connect with the verb e $\$ \mathrm{t} h$ - keeping in mind the threefold structure in Psalm 1:1.

- a mart wl of (Ps. 1:1, 5): The word sondaar is hardly ever used outside Biblical language and again one of the fairly unknown words to the younger generation. When it is used, it has similarly to goddeloses - a strongly down-played meaning and is being used jokingly and in a light-hearted manner. We chose to rather use the word oortreder - in the context of the relationship with God and the law, qualifying the matter again in a footnote.

- I oimwǹ (Ps. 1:1) presented the same difficulties as a ş ebwǹ and a mart wl wǹ. There were a number of possibilities: booswigte, boosdoeners, kwaadstokers, moeilikheidmakers. We agreed that the word described those who are posing a threat to society, with 
a strong connection to the aspect of a festering pest. Debating at length the pros and cons of each of the possibilities, the group agreed on moeilikheidmakers with another footnote that expanded on the semantic description of this group.

- Prepositions remain one of the most difficult categories when it comes to translation. The use of ej in Psalm 1, for instance, poses such a problem: en boul h/(Ps. 1:1, 5), en oblw/(Ps. 1:1), en t w/nomw/(Ps. 1:2 - twice), and en kairw/ (Ps. 1:3) could hardly be translated in each instance literally into Afrikaans with the preposition in plus the noun. The same prepositional phrase thus needed to be translated more dynamically within the context. Only the first occurrence in Psalm 1:5 was translated with in for the time being - but the translation of this verse still needs serious rethinking. (Cf., among others, Soisalon-Soininen, 1982: 190-200 and Wright, 1985:111-114 regarding the use of en in the LXX.)

- boukh (Ps. 1:1, 5) was discussed at length in our search for an appropriate translation equivalent. "Plan" somehow does not convey the same meaning anymore to a younger generation. It seems to contain a passive element, almost like a design of a building, rather than the active advice of the oortreders in Psalm 1:1 which steers the lifestyle of a person in the wrong direction. The word raad was taken as having a positive outcome, assisting in the right choices, and was thus not preferred in the context of Psalm 1:1. The word advies was then chosen in Psalm 1:1, but in Psalm 1:5 the same translation equivalent did not seem to work. In this instance "plan" remained more descriptive. This is a case where, if these two equivalents would be chosen in a final version, the style of the original text is definitely affected as the repetitiveness of boukh is now lost.

- t 0; qevhma (Ps. 1:2) with the translation equivalent of wil in the sense of "iemand se wil" is an expression that is not used by the youth anymore, except in relation to "a last will and testament". We chose here for strewe which is a more familiar word to the upcoming generation.

- ej tw/nomw/kuriou (Ps. 1:2) is another strange expression to teenagers and students. Although the word wet is being used by them, understanding what it means in the expression die wet van die Here is another matter. Siegert (2001:297) confirms the semantically laden background of this term: "Was wir im Nomos noch kaum finden, wird in den zukunftsorientierten, in neuen Si- 
tuationen neu gelesenen Prophetenbüchern eher üblich: Textzusätze, die ein eschatologisches Textverständnis fördern oder festschreiben ... Die Psalmen - schließlich ist David ein Prophet - und andere Hagiographia lassen ähnliche Tendenzen erkennen." In discussing different possibilities which included wet, voorskrifte (actually a translation equivalent for t $0 ;$ p r os t a g ma, cf. Ps. 2:7) and regulasies (which contains a strong negative element and resistance), we agreed that a better choice would rather be reëls. This word is a more neutral word, though still containing the prescriptive element, it is still widely in use and familiar in the domestic household and in other contexts of authority.

- The phrase para; tair diexodou t wǹ ullatwn (Ps. 1:3) presented itself as a difficult phrase to translate. Some members thought that the metaphoric idea of a crossing, as expressed by the plural noun $t a \sim$ diexodou , would suffice in a translation by die kruising van. Members though, who were in closer contact with a younger generation pointed out that this is unclear to them and they had difficulty in understanding the meaning of this expression. Playing with alternatives such as by die hoofkruisings van waters and samevloeiings van waterstrome, we decided then to rather use samevloeiing with an appropriate footnote which maintains the idea of a kruising and to translate it as by die samevloeiing van waterstrome. "The pious man is therefore planted in the bubbling brook of the Torah and the psalms (cf. Sirach, 15:9-10)." (Vos, 2005:54.)

- ginwskei (Ps. 1:6) involves here more than merely intellectual knowledge. Vos (2005:55-56) formulates it appropriately: "'Know' has more than an intellectual meaning here; it is filled with an emphatic sense of care, love, intimate concern and implies the sharing of someone's lot." Our team was aware of this difference in meaning and decided not to translate it with ken as this would indeed be understood to be intellectual knowledge. We discussed the possibility of insig hê, but were not of the same opinion on this. Theologically, how could the kurio have insight if everything is known to him anyway? We finally decided to rather use bekend wees met ...

\subsection{Being poetical language - to what extend would a literal or a dynamic translation be more appropriate?}

The psalms represent poetic language. Hengel (2002:106) is of the opinion that "the christological hymnody of early Christianity is also 
based on messianic psalms such as Psalms 2, 8, 22, 45, 69, 89, 118, etc.". The structure in which the authors wrote and their economy of words particularly pose unique challenges to any translation. It is not always possible to translate again into poetic language. What complicated the matter even more, was that the LXX version of the psalms is already a translation of a Hebrew Vorlage that was often initially written in poetic style. Regarding the rhythm of the Greek Psalm 1, Siegert (2001:182-183) refers to the fact that it shows clear signs of "überlieferten Silbenquantitäten". The rhythm, though, was not implemented mechanically, but had to fit in with the contents. "Der Rhythmus ist nicht am Platze, wo nur verneint, ja verspottet, aber nicht ermahnt wird, etwa in Ps. 1,6 ..." (Siegert, 2001:184.)

Some examples would suffice in this regard:

- In Ps. 1:1 three clear stichae are noticable:

ouk ejor eugh ej boul h/as ebwǹ

kai;ej odwlamart wl wn ouk es th

kai;ej i;kaqedran I oimwǹ ouk ekaqis en

When translating these phrases then, one should keep in mind, on the one hand, the poetic structure and, on the other hand, choosing words and phrases that comply to the same meaning and which are clearly understood by a younger generation. This poses an interesting challenge.

- Another example is to be found in Psalm 2:3 where the wordplay between diarrhxwmen and aporriy wmen (both restricted only to the LXX), is striking. It is about impossible to maintain this wordplay stylistically in a meaningful translation. Furthermore, the Greek Psalm 2 displays clear changes in the tense form and mood: In Psalm 2:1 and 2 the aorist is used consecutively in all four verbs; in verses 3-5 the futurum is used consecutively in all six verbs; verses $6-7 \mathrm{a}$ forms an introduction to the direct words following in verses $7 b-9$, spoken by the kuri 0 "to me" (p r o $\forall$ me); whereas verses 10-12a make use of four imperatives; verse $12 b$ and $12 \mathrm{~d}$ use the passive aorist subjunctive 3rd person singular and sandwich it in with a middle futurum indicative 2nd person plural; verse $12 \mathrm{e}$ ends with the form makarioi similar to Psalm 2:1 which started with makario . 


\subsection{Given the pace of translation and the extend of the project, it will take quite a number of years to complete}

The translating group tried to meet on a weekly basis, but only during term time. The idea was that nobody would prepare at home, so that the process would only be done as a team during the weekly gatherings. We soon discovered that we were translating at an extremely slow pace, initially at a pace of one verse every two weeks until we extended our one hour sessions to two hours. The pace remained the same, but now it became possible to complete at least one verse per session. Lately, though, the pace increased, sometimes even to three verses in a single session. This happened as team members found their own place in the group, as consensus was reached on the use of particular terminology that occur repeatedly, and as the translating criteria that the group set for itself became the parameters of what ought to be done.

Given this current pace, however, it would take about seventeen years (!) to complete the first draft of the circa 2500 verses in the psalms and odes at an optimistic rate of five verses per session and when meeting for thirty sessions per year. This raises a number of questions: What about changes in a constant changing and dynamic language such as Afrikaans? What about additions to the pool of textual witnesses and the foreseen critical edition of the Greek text of the psalms? Is it realistic to continue with this venture as a mere hobby and a reading exercise for post-graduate students, or should it be taken more seriously? Is it realistic to continue doing this with one single group, or should more teams be involved and the work be divided? Should the process be revised, for example where members translate individually in advance and only certain points are then debated? These are the most important questions facing our part-time venture at the moment.

\subsection{Existing dictionaries and grammars are mainly focused on New Testament Greek - not on the LXX}

Some words obviously occur only in the LXX and not in the New Testament. When consulting a number of Greek-English lexicons, these words are not always to be found there either. Particularly the need for a semantically based lexicon for the LXX in this regard should be noted. This leads to greater difficulties in determining what a particular term might have meant in Greek to the translators of the LXX. Some examples will suffice: diarrhxwmen (Ps. 2:3); a porriy wmen (Ps. 2:3); ekgel a s et a i (Ps. 2:4). 


\section{Conclusion}

What started as a part-time hobby which is thoroughly enjoyed by a small number of participants, has the potential to become an estimated seventeen year project. Apart from the problems and challenges briefly referred to above, the biggest challenge probably relates to the viability of this project. Should this only be measured against an economically viable market as the only outcome, and then, most likely, be aborted the sooner the better? Or are the implications greater than what can be measured in terms of economic viability, and to be of value for a relatively small group of Afrikaans mother-tongue speakers for generations to come?

This brings us to a crossroads situation. Should we continue with this venture in private with a small team of interested students at our own pace and costs, or should we enter an advanced and more professional stage where we explore the possibilities to co-operate with other colleagues and institutions? If the latter seems to be the better option, what would its implications be and how should we proceed? Our hope is that the words of Psalm 1:3 would become a reality regarding our bold venture: panta, o\$a ah poinl ka t euodwgh s et a i - Alles wat hy sou aanpak sal voorspoedig wees.

\section{List of references}

CONYBEARE, F.C. \& STOCK, G. 1981. Selections from the Septuagint. New York: New Rochelle. (College Classical Series.)

COOK, J. 2005. Novel developments in Septuagint research. Old Testament essays, 18:531-541.

FERNÁNDEZ MARCOS, N. 2000. The Septuagint in context: introduction to the Greek version of the Bible. Leiden: Brill.

FLINT, P.W. 1997. The Dead Sea psalms scrolls and the Book of Psalms. Leiden: Brill.

HENGEL, M. 2002. The Septuagint as Christian scripture: its prehistory and the problem of its canon. London: Clark.

JELLICOE, S. 1989. The Septuagint and modern study. Indiana: Eisenbrauns.

JOBES, K.H. \& SILVA, M. 2000. Invitation to the Septuagint. Michigan: Baker.

KRAUS, H-J. 1978. Psalmen. 1. Teilband: Psalmen 1-59. Neukirchen: Neukirchener Verlag. (BKAT XV/1.)

LAMPARTER, H. 1961. Das Buch der Psalmen 1: Psalm 1-72. Stuttgart: Calwer. (Die Botschaft des Alten Testaments, 14.)

LUST, J., EYNIKEL, E. \& HAUSPIE, K., eds. 1996. A Greek-English lexicon of the Septuagint. Stuttgart: Deutsche Bibelgesellschaft.

NEW BIBLE DICTIONARY. 1962. Wheaton: Tyndale House. [Libronix online.] NIDA, E.A. 1981. Signs, sense, translation. Pretoria: University of Pretoria.

NIDA, E.A. \& TABER, C.R. 1974. The theory and practice of translation. Leiden: Brill. 
PIETERSMA, A. 2002. A new paradigm for addressing old questions: the relevance of the interlinear model for the study of the Septuagint. (In Cook, J., ed. Bible and computer: the Stellenbosch AIBI-6 conference. Proceedings of the Association Internationale Bible et Informatique "From Alpha to Byte". University of Stellenbosch 17-21 July 2000. Leiden: Brill. p. 337-364.)

PIETERSMA, A. 2003. When David fled Abessalom: a commentary on the third Psalm in Greek. (In Paul, S.M., Kraft, R.A., Schiffman, L.H. \& Fields, W.W., eds. Emanuel: studies in Hebrew Bible, Septuagint and Dead Sea scrolls in honor of Emanuel Tov. Leiden: Brill. p. 645-659.)

PRINSLOO, W.S. 1984. Van kateder tot kansel: 'n eksegetiese verkenning van enkele psalms. Pretoria: NG Kerkboekhandel.

PRINSLOO, W.S. 2000. Die lof van my God solank ek lewe: verklaring van 'n aantal psalms deur Willem S. Prinsloo. Irene: Medpharm.

RAHLFS, A. 1979. Psalmi cum Odis: Septuaginta. Vol. X. Göttingen: Vandenhoeck \& Ruprecht.

SCHRÖDER, C. 2001. Alphabetische Zusammenstellung auffälliger Neologismen der Septuaginta, 61-69. (In Fabry, H-J. \& Offerhaus, U., Hrsg. Im Brennpunkt: die Septuaginta. Studien zur Entstehung und Bedeutung der Griechischen Bibel. Stuttgart: Kohlhammer. (BWANT, 153.)

SIEGERT, F. 2001. Zwischen Hebräischen Bibel und Altem Testament: eine Einführung in die Septuaginta. Münster: Lit Verlag. (MJSt, 9.)

SOISALON-SOININEN, I. 1982. en für eij in der Septuaginta. Vetus testamentum, 32:190-200.

STEUDEL, A. 1994. Der Midrasch zur Eschatologie aus der Qumrangemeinde (4QMidrEschat ${ }^{\text {a.b }}$ ). Leiden: Brill.

STEYN, G.J. 1995. Septuagint quotations in the context of the Petrine and Pauline speeches of the Acta Apostolorum. Kampen: Kok.

STEYN, G.J. 2003. Psalm 2 in Hebrews. Neotestamentica, 37(2):262-282.

SWETE, H.B. 1914. Introduction to the Old Testament in Greek. Cambridge: Cambridge University Press.

VAN UCHELEN, N.A. 1979. Psalmen: deel 1 (1-40). Nijkerk: Callenbach. (Prediking van het Oude Testament.)

VOS, C.J.A. 2005. Theopoetry of the psalms. Pretoria: Protea Book House.

WRIGHT III, B.C. 1985. A note on the statistical analysis of Septuagintal syntax. Journal of Biblical literature, 104:111-114.

\section{Key concepts:}

Bible translation

Psalms

Septuagint

Kernbegrippe:

Bybelvertaling

Psalms

Septuaginta 


\section{Text and translation of psalms 1-3}

\section{Psalm 1}

\begin{tabular}{|c|c|}
\hline Göttingen LXX Psalmi cum Odis & Afrikaans Draft Translation ( ) \\
\hline 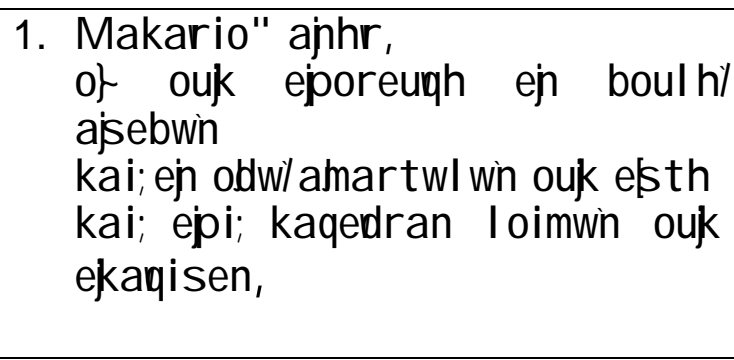 & $\begin{array}{l}\text { Gelukkig }{ }^{3} \text { is die mens } \\
\text { wat nie die advies van goddeloses } \\
\text { nagevolg } \\
\text { net nie, } \\
\text { nie die rigting van oortreders } \\
\text { ingeslaan } \\
\text { in het nie, } \\
\text { en nie op die stoel }{ }^{8} \text { van moeilikheid- } \\
\text { makers }{ }^{9} \text { gesit }^{10} \text { het nie, }\end{array}$ \\
\hline 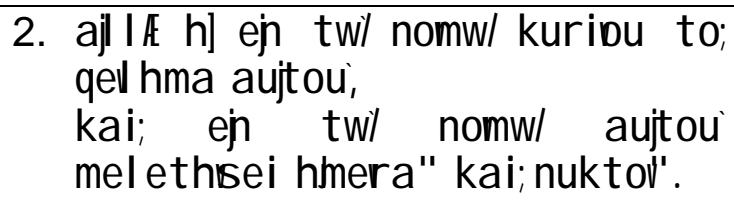 & $\begin{array}{l}\text { maar wie se strewe eerder die reëls } \\
\text { van die Here is, } \\
\text { en wat sy reëls dag en nag sal } \\
\text { oordink! } 11\end{array}$ \\
\hline 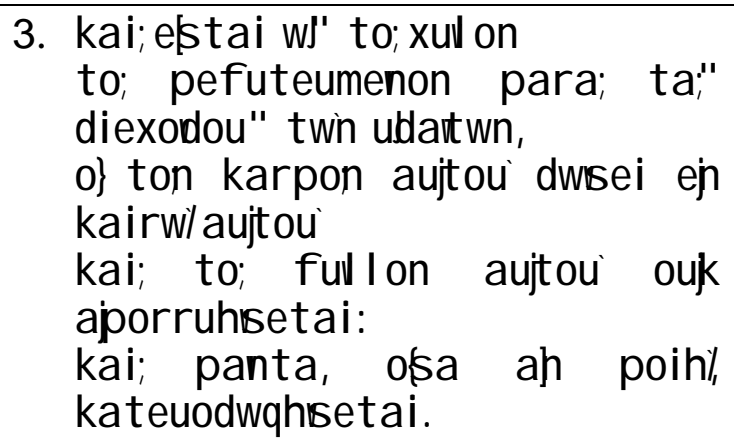 & $\begin{array}{l}\text { Hy sal soos 'n boom wees wat } \\
\text { by die samevloeiing }{ }^{12} \text { van water- } \\
\text { strome geplant is, } \\
\text { wat sy vrugte tydig sal gee, } \\
\text { en wie se blare } 13 \text { nie sal afval nie. } \\
\text { Alles wat hy sou aanpak sal voor- } \\
\text { spoedig wees. }\end{array}$ \\
\hline
\end{tabular}

3 'n Toestand van tevredenheid en voorspoed.

$4 \quad$ Mense wat God nie ken of wil ken nie.

$5 \quad$ Element van beweging.

$6 \quad$ Mense wat nie die wet van God nakom nie, en daarom skuldig is.

$7 \quad$ Element van staan.

8 Die frase "op die stoel sit" is 'n figuurlike uitdrukking vir 'n gesagsposisie.

$9 \quad$ Mense wat die samelewing bedreig en lewens verwoes.

10 Element van sit.

11 Deur bestudering en nadenke die inhoud van 'n saak herhalend aktief in te oefen.

12 'n Kruising.

13 Enkelvoud word hier gebruik, maar meervoud word bedoel. 


\begin{tabular}{|c|c|}
\hline 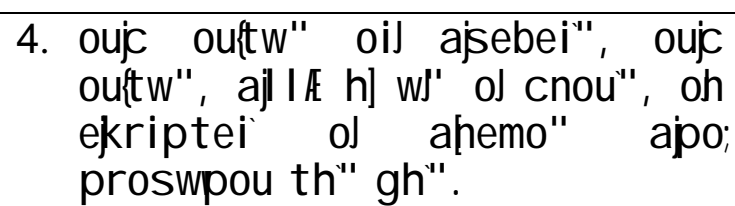 & $\begin{array}{l}\text { Nie só is die goddeloses nie! Nie só } \\
\text { nie! Maar soos die kaf wat die wind } \\
\text { opwaai van die gesig van die aarde } \\
\text { af. }\end{array}$ \\
\hline $\begin{array}{l}\text { 5. dia; touto ouk ajnasthsontai } \\
\text { aśebei" ej krisei } \\
\text { oude; amartwloi; en boulhy } \\
\text { dikaiwn, }\end{array}$ & $\begin{array}{l}\text { Daarom sal die goddeloses nie } \\
\text { opgewek word in die oordeel nie, } \\
\text { of oortreders volgens die plan van } \\
\text { regverdiges }{ }^{14} \text { nie, }\end{array}$ \\
\hline $\begin{array}{l}\text { 6. ołi ginwskei kurio" opdon } \\
\text { dikaiwn, kai; oblo", asjebwn } \\
\text { apol eitai. }\end{array}$ & $\begin{array}{l}\text { Want die Here is bekend met die } \\
\text { koers van die regverdiges, maar die } \\
\text { koers wat die goddeloses volg, } \\
\text { verwoes Hy. }\end{array}$ \\
\hline
\end{tabular}

\section{Psalm 2}

\begin{tabular}{|c|c|}
\hline Göttingen LXX Psalmi cum Odis & Afrikaans Draft Translation $@$ \\
\hline $\begin{array}{l}\text { 1. I ka t i vef ruaxan equh } \\
\text { kai; l a oi; ; ejel eths an kenay }\end{array}$ & $\begin{array}{l}\text { Waarom het die heidennasies in } \\
\text { opstand gekom en het die volke } \\
\text { tevergeefs gekonkel? }\end{array}$ \\
\hline $\begin{array}{l}\text { 2. paresthsan oij basilei" th" } \\
\text { gh" kai; oij a[conte" } \\
\text { sunheghsan epi; to; a ut } 0 ; \text { kata; } \\
\text { tou" kuriou kai; kata; tou" } \\
\text { cristou'autou" } \\
\text { diayal ma }\end{array}$ & $\begin{array}{l}\text { Die konings van die aarde het saam } \\
\text { gestaan en die heersers is versamel } \\
\text { op een plek teen die Here en teen sy } \\
\text { gesalfde. }{ }^{15} \\
\text { <Diapsalma>16 }\end{array}$ \\
\hline 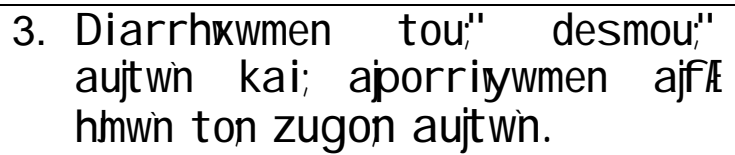 & $\begin{array}{l}\text { Ons sal hulle boeie afskeur en ons } \\
\text { sal hulle juk van ons af weggooi. }\end{array}$ \\
\hline $\begin{array}{l}\text { 4. of katoikwñ ej oujanoi" } \\
\text { ekgelasetai autouv, kai; ol } \\
\text { kuvio" ekmukthriei'aut ouv. }\end{array}$ & $\begin{array}{l}\text { Hy wat in die hemele woon sal hulle } \\
\text { uitlag en die Here sal hulle spot. }\end{array}$ \\
\hline 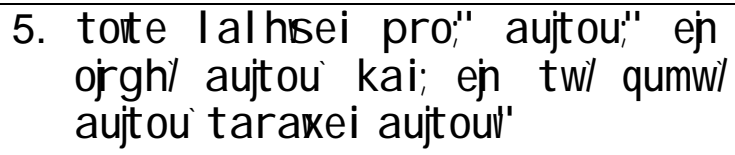 & $\begin{array}{l}\text { Dan sal Hy in sy woede met hulle } \\
\text { praat en in ' } n \text { woede-uitbarsting }{ }^{\mathbf{1 7}} \text { sal } \\
\text { Hy hulle in beroering bring. }\end{array}$ \\
\hline
\end{tabular}

14 Wetsgehoorsames wat vrygespreek is as gevolg van wetsonderhouding.

15 Die Griekse woord is "christus". Gesalfde dui hier op die koning.

16 Die term diapsalmos dui 'n breuk, oorgang of 'n musikale tussenspel aan. Dit is die Griekse vertaling van die Hebreeuse Sela.

17 Die bedoeling is nie om God voor te stel as 'n marionet wat onbeheersde buie beleef nie, maar om die intensiteit van God se oordeelsoomblik te beskryf. 
6. Egw; de; katestaghn basileu," Ek is as koning deur hom aangestel up $\mathbb{E}$ a uf ou' epi; Siwn ofo" to; op Sion, sy heilige berg, a gion a ut ou'

7. diaggevlwn to; prostagma kuriou

Kurio" eipen prov me

Uibv mou eij suv ejgw; shmeron gegemnhkavse,

8. aifhsai partE emou, kai; dwsw soi egnh thn klhronomian sou

kai; thn katascesin sou ta; perata th"gh",

ek wat die voorskrif van die Here verkondig: Die Here het vir my gesê: Jy is my seun, Ek het vandag aan jou geboorte gegee. 18

Vra vir my en ek sal heidene vir jou as erflating gee en die grense van die aarde $^{19}$ as jou besitting.

9. poimanei" aufou," ej rabdw/ Jy sal hulle met 'n ystersepter sidhral w' skeuò" keramew" regeer, 20 en soos 'n kleipot verpletter. sunt riy ei" a uf ouv".

10.kai; nuǹ, basilei", sumete, En nou, konings, neem kennis: laat paideughte, pante" oij julle 'n les geleer word, julle almal wat krimonte" thnghñ. die aarde regeer.

11. doul eusate $t w / k u r i w /$ en f obw/ Dien die Here met respek kai;agallias̀qe a ut w/ej tromw/ En prys Hom met ontsag

12.draxas qe paideia", $\quad$ Neem die opvoeding aan mhpot e ojgisqh/kurio"

kai;ajol eis qe ej oflou'dikaia". ołan ekkauqh/ej tarei ol qumo," a uf ou, makarioi pante" oijpepoiqote" ep FEa ut wl moenie dat die Here woedend word nie, en julle verwyder sal word vanaf die regte pad wanneer sy geduld opraak nie. 21

Gelukkig is almal wat oorreed is tot Hom.

\section{Psalm 3}

\begin{tabular}{|c|c|}
\hline Göttingen LXX Psalmi cum Odis & Afrikaans Draft Translation ( \\
\hline $\begin{array}{l}\text { 1. Y al mo; t w/Dauid, op ote } \\
\text { a pedidrasken apo;pros wpou } \\
\text { A bes sal wm tou'uipu'a ut ou: }\end{array}$ & $\begin{array}{l}\text { 1. 'n Dawidspsalm. } \\
\text { Toe hy van die teenwoordigheid } \\
\text { van sy seun, Absalom, weggevlug } \\
\text { het. }\end{array}$ \\
\hline $\begin{array}{l}\text { 2. Kurie, tiv ejlhqumghsan oil } \\
\text { qlibont eṽ meÉ } \\
\text { polloi;epanistant ai ej Femey }\end{array}$ & $\begin{array}{l}\text { 2. Here, waarom word my verdruk- } \\
\text { kers meer? } \\
\text { Baie rebelleer teen my! }\end{array}$ \\
\hline
\end{tabular}

18 Simboliese taal vir die aanstelling van 'n koning in sy amp.

19 Die bedoeling is "die hele aarde".

20 "Met 'n ystersepter regeer" is metaforiese taal vir "met streng, genadelose regering".

21 Letterlik: sy asem uitgebrand sou wees. 
3. polloi; legous in $\mathrm{th} / \mathrm{y}$ uch/mou ouk estin swthria autw/ej tw/ qewla ut ou:

di i y a I ma.

4. su; dev kurie, ajtilhmptwr mou eij doxa mou kai; uy wh̀ thn kef al ho mou.

5. f whh/mou pro," kurion ekekraxa, kai; ejhkousen mou ej ofou" agiou a uf ou.'
Baie praat oor my lewe:

"Daar is nie bevryding vir hom deur sy God nie!"

\section{Maar Ú, Here,}

di a y a I ma.

6. egw;ekoimhqhn kai;uknwsa, exhgerghn, obi kurio" ajtil hmy et a ivmou.

7. ouj f obhahsomai apo; muriadwn Iaou' twh̀ kuklw/ sunepitiqemenwn moi.

8. ajnasta, kurie, sws̀ on me, ol qeoü mou, ofli su; ejataxa" panta" tou," ejcraimontav moi mataiw", oplont a " a mart wl wh sunetriy a".

9. tou'kuriou hJ swthria, kai; eji; ton la on sou hJeulogia sou.
$\mathrm{U}$ is my beskermer,

$U$ is my eer,

en $U$ is die Een wat my kop oplig!

Ek het met my stem tot die Here geskreeu, ${ }^{22}$ en uit sy heilige berg het Hy my gehoor.

$<$ Diapsalma $>$

$<$ Diapsalma $>$

Ek is aan die slaap gemaak en ek het geslaap.

Ek is wakker gemaak, ${ }^{23}$ want die Here sal my help.

Ek sal nie bang word as tienduisende volke my omring terwyl hulle teen my optrek nie!

Staan op, Here! Red my, my God, want $U$ het al dié wat my sonder rede haat verslaan. $U$ het die tande van sondaars verpletter.

Die bevryding is van die Here en sy roem is op sy volk.

22 Om in wanhoop uit te roep, of te skree vir hulp.

23 Die passiewe soos in "is aan die slaap gemaak" en "is wakker gemaak" dui gewoonlik op handelinge van God. 